method described in this paper allows large volumes of sample to be preconcentrated and high concentration factors can be achieved. This is important in trace analysis. This method would be applicable to the analysis of drugs of abuse in physiological fluids such as urine and blood. Although extraction of drugs of abuse from urine and blood is well established no attempts have yet been made to analyze these on-line by coupling SFE to chromatographic techniques. Off-line analysis of urine, blood, liver, kidney, and hairs is underway.

We warmly thank $M$. Rupper Haering for technical assistance and the Swiss National Scientific Research Foundation for financial support.

Received: January 20, 1992

[1] M.L. Lee, K.E. Markides, 'Analytical Supercritical Fluid Chromatography and Extraction', Eds.M.L.Lee amd K.E. Markides, Chromatography Conferences Inc., Provo, 1990, p. 313.
[2] S.B. Hawthorne, Anal. Chem. 1990, 62 , $633 \mathrm{~A}$.

[3] J.W. King, J. Chromatogr. Sci. 1989, 27, 355 .

[4] J.L. Veuthey, M. Caude, R. Rosset, Analusis $1990,18,103$.

[5] R.W. Vannoort, J.P. Chervet, H. Lingeman, G.J. Dejong, U.A. Brinkman, J. Chromatogr. 1990, 505, 45.

[6] K.G. Furton and J. Rein, Anal. Chim. Acta 1990, 237, 99.

[7] J.D. Pinkston, T.E. Delaney, D.J. Bowling, T.L. Chester, High Resolut. Chromatogr.1991, 14, 401 .

[8] E. Stahl, J. Chromatogr. 1977, 142, 15.

[9] S.M. Fields, K. Grolimund, J. High Resolut. Chromatogr. 1988, 727, 11

[10] F. David, P. Sandra, J. High Resolut. Chromatogr. 1988, 897, 11

[11] O. Gyllenhaal, J. Vessman, J. Chromatogr. $1990,516,415$.

[12] T.L. Chester.D.P. Innis, J. High Resolut. Chromatogr. 1986, 9, 178

[13] J.L. Janicot, M. Caude, R. Rosset, J. Chromatogr. 1988, 437, 351 .

[14] T.L. Chester, D.P. Innis, J. High Resolut Chromatogr. 1986, 9, 561.

[15] R.M. Smith, M. Sanagi, J. Chromatogr. $1990,505,147$.

[16] J.L. Veuthey, W. Haerdi, J. Chromatogr. $1990,515,385$.

[17] R.M. Smith, M. Sanagi, J. Chromatogr. $1989,483,51$
[18] R.M. Smith, M. Sanagi, J. Chromatogr. 1989, 48I, 63.

19] D.W. Roberts, I.D. Wilson, Methodol. Surv. Biochem. Anal. 1990, 257

[20] W.Steuer, J. Baumann, F. Erni, J. Chromatogr. 1990, 500, 469.

[21] D.W. Later, B.E. Richter, D.E. Knowles, M.R. Andersen, J. Chromatogr. Sci. 1986, 24, 249.

[22] G.A. Mackay, G.D. Reed, J. High Resolut. Chromatogr. 1991, 14, 537.

[23] J.M. Mulcahey, L.T. Taylor, J. High Resolut. Chromatogr. 1990, 13, 393.

[24] S.H.Y. Wong, Clin. Chem. 1989, 35, 1293.

[25] R.L. Eatherton, M.A. Morissey, H.H. Hill, Anal. Chem. 1988, 60, 2240.

[26] L. Karlsson, L. Mathiasson, J. Akesson, J. Jonsson, J. Chromatogr. 1991, 557, 99.

[27] J.L. Janicot, M. Caude, R. Rosset, J.L. Veuthey, J. Chromatogr. 1990, 505, 247.

[28] B.E. Richter, D.E. Knowles, M.R. Andersen, N.L. Porter, E.R. Campbel, J. High Resolut. Chromatogr. 1988, II, 29.

[29] M.L. Lee, B. Xu, E.C. Huang, N.M. Djordjevic, H.C.K. Chang, K.E. Markides $J$. Microcol, Sep. 1989, $1,7$.

[30] B.E. Berg, T. Greibrokk, J. High Resolut Chromatogr. 1989, 12, 322

[31] K. Sugiyama, M. Saito, T. Hondo, M. Senda, J. Chromatogr. 1985, 332, 107.
Chimia 46 (1992) 148-151

(c) Schweiz Chemiker-Verband; ISSN 0009-4293

\title{
Photophysical Behavior of Malachite Green in Solid and Liquid Media
}

\section{Renata Reisfeld ${ }^{a}$ ), Valery Chernyak $^{a}$ ), and Christian K. Jørgensen $\left.{ }^{b}\right)^{*}$}

Abstract. Malachite Green (MG) incorporated in glass appears in four forms. In acidic glasses, yellow $\mathrm{H}(\mathrm{MG})^{2+}$ protonated dications; the green monocation $\mathrm{MG}^{+}$in $\mathrm{H}_{2} \mathrm{O}$ at $\mathrm{pH} 4$ to 6 ; the colorless carbinol base $\mathrm{HO}(\mathrm{MG})$ at higher $\mathrm{pH}$; and a new purple species in certain glasses prepared by mineral acid catalysis. Uniquely high luminescence yields indicate formation of chemical bonds between $\mathrm{MG}^{+}$and the silicate groups, suggesting Lewis-acid behavior of three-coordinated carbon. Novel cascade emission is observed from the three first excited singlets $S_{1}, S_{2}$, and $S_{3}$. In sol-gel glasses, green $\mathrm{MG}^{+}$bleaches reversibly under illumination

\section{Introduction}

The triphenylmethane colorant Malachite Green (MG) incorporated in sol-gel glasses or other polymers recently attracted attention due to its unusual optical properties, manifested also on a very shorttime scale [1]

A systematic study of absorption and in particular the novel emission spectra showing high luminescence yields as a function of preparative procedure [2][3] give the motivation to attempt a rationalization of the unusual spectroscopy based on a general distinction between the coordination numbers $N=3$ and $N=4$ of carbon in aromatic molecules and ions.

It is especially appealing to study the monocationic form of Malachite Green $\mathrm{MG}^{+}\left(\left[\mathrm{PhC}\left(\mathrm{C}_{6} \mathrm{H}_{4} \mathrm{NMe}_{2}\right)_{3}\right]^{+}\right)$and its proto- nated form in gel glasses [3], in which the luminescent ions are situated in a small isolated cavity. Recently, a gel glass composed of $\mathrm{SiO}_{2}$ and $\mathrm{ZrO}_{2}$ [1] containing $\mathrm{MG}^{+}$was shown to become reversibly transparent to incident energies of microjoules with a recovery time of picoseconds.

In (MG) the colorless form is attributed here to the four-coordinated C-atom in the carbinol $\mathrm{HO}(\mathrm{MG})$ and the colored forms to three-coordinated $\mathrm{C}$-atom in green $\mathrm{MG}^{+}$and in the yellow protonated dication $\mathrm{H}(\mathrm{MG})^{2+}$. Our suggestions are based on the following consideration:

The most frequent coordination number of non-aromatic $\mathrm{C}$-atom is 4 . Planar aliphatic compounds with $N=3$ such as formate $\mathrm{HCO}_{2}^{-}$, aqueous carbonic acid $(\mathrm{HO})_{2} \mathrm{CO}$ and bicarbonate $\mathrm{HOCO}_{2}^{-}$do not usually absorb in the visible or near UV.

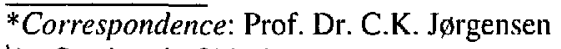

b) Section de Chimie

Université de Genève

30, quai Ernest-Ansermet

$\mathrm{CH}-12$ ll Genève 4

a) Prof. Dr. R.Reisfeld (Enrique Berman Professor of Solar Energy)

Dr. V. Chernyak

Department of Inorganic Chemistry

The Hebrew University

91904 Jerusalem, Israel 
method described in this paper allows large volumes of sample to be preconcentrated and high concentration factors can be achieved. This is important in trace analysis. This method would be applicable to the analysis of drugs of abuse in physiological fluids such as urine and blood. Although extraction of drugs of abuse from urine and blood is well established no attempts have yet been made to analyze these on-line by coupling SFE to chromatographic techniques. Off-line analysis of urine, blood, liver, kidney, and hairs is underway.

We warmly thank $M$. Rupper Haering for technical assistance and the Swiss National Scientific Research Foundation for financial support.

Received: January 20, 1992

[1] M.L. Lee, K.E. Markides, 'Analytical Supercritical Fluid Chromatography and Extraction', Eds.M.L.Lee amd K.E. Markides, Chromatography Conferences Inc., Provo, 1990, p. 313.
[2] S.B. Hawthorne, Anal. Chem. 1990, 62 , $633 \mathrm{~A}$.

[3] J.W. King, J. Chromatogr. Sci. 1989, 27, 355 .

[4] J.L. Veuthey, M. Caude, R. Rosset, Analusis $1990,18,103$.

[5] R.W. Vannoort, J.P. Chervet, H. Lingeman, G.J. Dejong, U.A. Brinkman, J. Chromatogr. 1990, 505, 45.

[6] K.G. Furton and J. Rein, Anal. Chim. Acta 1990, 237, 99.

[7] J.D. Pinkston, T.E. Delaney, D.J. Bowling, T.L. Chester, High Resolut. Chromatogr.1991, 14, 401 .

[8] E. Stahl, J. Chromatogr. 1977, 142, 15.

[9] S.M. Fields, K. Grolimund, J. High Resolut. Chromatogr. 1988, 727, 11

[10] F. David, P. Sandra, J. High Resolut. Chromatogr. 1988, 897, 11

[11] O. Gyllenhaal, J. Vessman, J. Chromatogr. $1990,516,415$.

[12] T.L. Chester.D.P. Innis, J. High Resolut. Chromatogr. 1986, 9, 178

[13] J.L. Janicot, M. Caude, R. Rosset, J. Chromatogr. 1988, 437, 351 .

[14] T.L. Chester, D.P. Innis, J. High Resolut Chromatogr. 1986, 9, 561.

[15] R.M. Smith, M. Sanagi, J. Chromatogr. $1990,505,147$.

[16] J.L. Veuthey, W. Haerdi, J. Chromatogr. $1990,515,385$.

[17] R.M. Smith, M. Sanagi, J. Chromatogr. $1989,483,51$
[18] R.M. Smith, M. Sanagi, J. Chromatogr. 1989, 48I, 63.

19] D.W. Roberts, I.D. Wilson, Methodol. Surv. Biochem. Anal. 1990, 257

[20] W.Steuer, J. Baumann, F. Erni, J. Chromatogr. 1990, 500, 469.

[21] D.W. Later, B.E. Richter, D.E. Knowles, M.R. Andersen, J. Chromatogr. Sci. 1986, 24, 249.

[22] G.A. Mackay, G.D. Reed, J. High Resolut. Chromatogr. 1991, 14, 537.

[23] J.M. Mulcahey, L.T. Taylor, J. High Resolut. Chromatogr. 1990, 13, 393.

[24] S.H.Y. Wong, Clin. Chem. 1989, 35, 1293.

[25] R.L. Eatherton, M.A. Morissey, H.H. Hill, Anal. Chem. 1988, 60, 2240.

[26] L. Karlsson, L. Mathiasson, J. Akesson, J. Jonsson, J. Chromatogr. 1991, 557, 99.

[27] J.L. Janicot, M. Caude, R. Rosset, J.L. Veuthey, J. Chromatogr. 1990, 505, 247.

[28] B.E. Richter, D.E. Knowles, M.R. Andersen, N.L. Porter, E.R. Campbel, J. High Resolut. Chromatogr. 1988, II, 29.

[29] M.L. Lee, B. Xu, E.C. Huang, N.M. Djordjevic, H.C.K. Chang, K.E. Markides $J$. Microcol, Sep. 1989, $1,7$.

[30] B.E. Berg, T. Greibrokk, J. High Resolut Chromatogr. 1989, 12, 322

[31] K. Sugiyama, M. Saito, T. Hondo, M. Senda, J. Chromatogr. 1985, 332, 107.
Chimia 46 (1992) 148-151

(c) Schweiz Chemiker-Verband; ISSN 0009-4293

\section{Photophysical Behavior of Malachite Green in Solid and Liquid Media}

\section{Renata Reisfeld ${ }^{a}$ ), Valery Chernyak $^{a}$ ), and Christian K. Jørgensen $\left.{ }^{b}\right)^{*}$}

Abstract. Malachite Green (MG) incorporated in glass appears in four forms. In acidic glasses, yellow $\mathrm{H}(\mathrm{MG})^{2+}$ protonated dications; the green monocation $\mathrm{MG}^{+}$in $\mathrm{H}_{2} \mathrm{O}$ at $\mathrm{pH} 4$ to 6 ; the colorless carbinol base $\mathrm{HO}(\mathrm{MG})$ at higher $\mathrm{pH}$; and a new purple species in certain glasses prepared by mineral acid catalysis. Uniquely high luminescence yields indicate formation of chemical bonds between $\mathrm{MG}^{+}$and the silicate groups, suggesting Lewis-acid behavior of three-coordinated carbon. Novel cascade emission is observed from the three first excited singlets $S_{1}, S_{2}$, and $S_{3}$. In sol-gel glasses, green $\mathrm{MG}^{+}$bleaches reversibly under illumination

\section{Introduction}

The triphenylmethane colorant Malachite Green (MG) incorporated in sol-gel glasses or other polymers recently attracted attention due to its unusual optical properties, manifested also on a very shorttime scale [1]

A systematic study of absorption and in particular the novel emission spectra showing high luminescence yields as a function of preparative procedure [2][3] give the motivation to attempt a rationalization of the unusual spectroscopy based on a general distinction between the coordination numbers $N=3$ and $N=4$ of carbon in aromatic molecules and ions.

It is especially appealing to study the monocationic form of Malachite Green $\mathrm{MG}^{+}\left(\left[\mathrm{PhC}\left(\mathrm{C}_{6} \mathrm{H}_{4} \mathrm{NMe}_{2}\right)_{3}\right]^{+}\right)$and its proto- nated form in gel glasses [3], in which the luminescent ions are situated in a small isolated cavity. Recently, a gel glass composed of $\mathrm{SiO}_{2}$ and $\mathrm{ZrO}_{2}$ [1] containing $\mathrm{MG}^{+}$was shown to become reversibly transparent to incident energies of microjoules with a recovery time of picoseconds.

In (MG) the colorless form is attributed here to the four-coordinated C-atom in the carbinol $\mathrm{HO}(\mathrm{MG})$ and the colored forms to three-coordinated $\mathrm{C}$-atom in green $\mathrm{MG}^{+}$and in the yellow protonated dication $\mathrm{H}(\mathrm{MG})^{2+}$. Our suggestions are based on the following consideration:

The most frequent coordination number of non-aromatic $\mathrm{C}$-atom is 4 . Planar aliphatic compounds with $N=3$ such as formate $\mathrm{HCO}_{2}^{-}$, aqueous carbonic acid $(\mathrm{HO})_{2} \mathrm{CO}$ and bicarbonate $\mathrm{HOCO}_{2}^{-}$do not usually absorb in the visible or near UV.

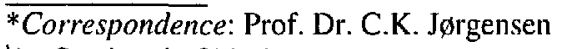

b) Section de Chimie

Université de Genève

30, quai Ernest-Ansermet

$\mathrm{CH}-12$ ll Genève 4

a) Prof. Dr. R.Reisfeld (Enrique Berman Professor of Solar Energy)

Dr. V. Chernyak

Department of Inorganic Chemistry

The Hebrew University

91904 Jerusalem, Israel 
The situation is different in strongly conjugated compounds with which we are dealing here. In most of these conjugated systems the compounds having four coordinated $\mathrm{C}$-atom are colorless, while those having three coordinated $\mathrm{C}$-atom become strongly colored. Thus, triphenylcarbinol [4] $\mathrm{HOCPh}_{3}$ reacts with strong acids to form the orange $\mathrm{Ph}_{3} \mathrm{C}^{+}$of which salts with $\mathrm{BF}_{4}^{-}, \mathrm{PF}_{6}^{-}, \mathrm{AsF}_{6}^{-}, \mathrm{SbF}_{6}^{-}$, and $\mathrm{ClO}_{4}^{-}$can be isolated [5][6]. Also strongly alkaline solvents (e.g. $\mathrm{NH}_{2}^{-}$in liquid ammonia) form red carbanions $\mathrm{Ph}_{3} \mathrm{C}^{-}$with $\mathrm{N}=3$ contrary to the colorless molecules with $N=4$ $\mathrm{Ph}_{3} \mathrm{CH}$ and $\mathrm{Ph}_{3} \mathrm{CCl}$.

The new aspect here is the effect of oxygen containing anions in adjacent sites for rearrangements of strongly colored $(N=3)$ and related $(N=4)$ aromatics. Many triphenylmethane colorants such as Crystal Violet (= Gentian Violet) $\mathrm{C}\left[\mathrm{C}_{6} \mathrm{H}_{4} \mathrm{NMe}_{2}\right]_{3}{ }^{+}$(in this note $\mathrm{CV}^{+}$) with three, and Malachite Green $\mathrm{PhC}\left[\mathrm{C}_{6} \mathrm{H}_{4} \mathrm{NMe}_{2}\right]_{2}{ }^{+}$(in this note $\mathrm{MG}^{+}$) with two $p$-(dimethylamino) substituents were studied (in Jerusalem) from the point of view of luminescence in highly viscous solvents, and in sol-gel prepared glasses [2][3]. These two colorants behave as immediately reversible $\mathrm{pH}$ indicators in aqueous acid, $\mathrm{MG}^{+}$forming yellow $\mathrm{H}(\mathrm{MG})^{2+}$ and Crystal Violet green $\mathrm{H}(\mathrm{CV})^{2+}$ and yellow $\mathrm{H}_{2}(\mathrm{CV})^{3+}$ when protonating the $N=3 \mathrm{~N}$-atoms to $\mathrm{N}=4$ (the authors do not know to what extent this protonation may modify the coplanarity of the 11 nuclei in $\mathrm{C}_{6} \mathrm{H}_{4} \mathrm{~N}$ ). The strongly colored cations all have $N=3$ of the central $\mathrm{C}$-atom coordinated to the three $\mathrm{C}_{6}$ hexagons. At a given $\mathrm{pH}$, however, slow equilibria are established between colorless carbinols $\mathrm{H}_{2} \mathrm{O}(\mathrm{MG})$ and protonated $\left(\mathrm{H}_{2} \mathrm{O}\right) \mathrm{MG}^{+}$studied extensively [7-10], also for differing MG substituted on several positions on the remaining $\mathrm{Ph}$ ring.

In view of the strong (and quite broad) absorption bands of the $N=3$ species, it is not easy to be certain that adjacent, weaker bands (a band 30 times weaker than the $620-\mathrm{nm}$ band of green $\mathrm{MG}^{+}$would be as intense per mol as the 526-nm band of permanganate) do not occur in the $N=4$ hydroxy species (although aliphatic $\mathrm{Me}_{3} \mathrm{COH}_{2}{ }^{+}$and $\mathrm{MeOH}_{2}{ }^{+}$are strictly colorless; these 'aqua ions' are only slightly more acidic than $\mathrm{H}_{3} \mathrm{O}^{+}$). Anyhow, the slow rearrangements between $N=3$ and 4 make the intensities of the absorption maxima of $N=3$ apparently less reproducible [11][12].

Förster and Hoffman [13] found nearIR luminescence of $\mathrm{CV}^{+}$to be almost imperceptible in solvents of low viscosity, but the yield increases almost proportionally to the square root of viscosity. Analogous results were reported [14] for red emission of $\mathrm{MG}^{+}$, although with yields remaining below a few percent. The rapid nonradiative relaxation in $\mathrm{H}_{2} \mathrm{O}$ of the emitting state with lifetime [15] of only 3 ps as compared with the radiative lifetime of few ns, is connected with the crossing [1][13-17] of two multidimensional BornOppenheimer potential surfaces. Here, a set of internuclear distances is highly modified, for instance by a strong relative rotation of the $\mathrm{Ph}$ rings, allowing the ground state and the luminescent state to cross or to approach closely.

\section{Experimental Results on the Ground-} state

The sol-gel glasses with Malachite Green were prepared from $(\mathrm{MeO})_{4} \mathrm{Si}$ (TMOS), containing varying concentrations of $\mathrm{H}_{2} \mathrm{O}$ and $\mathrm{MeOH}$, and using the following catalysts: methacrylic acid, $\mathrm{AcOH}, \mathrm{HF}, \mathrm{H}_{3} \mathrm{PO}_{4}, \mathrm{HCl}, \mathrm{HNO}_{3}$, or $\mathrm{H}_{2} \mathrm{SO}_{4}$, or dilute $\mathrm{NaOH}$ and one experiment without any catalyst. The detailed ratio between components and the serial of preparation may be found in [2]. The temperature of drying varied between 50 and $100^{\circ}$. Glasses prepared using methacrylic acid, $\mathrm{AcOH}, \mathrm{HF}$, or $\mathrm{NaOH}$ as catalysts showed the blue green color of monocation $\mathrm{MG}^{+}$(predominant at $\mathrm{pH} 4$ to 6 in aqueous solutions) with absorption peaks close to 615,420 , and $312 \mathrm{~nm}$ and emission typically at $650 \mathrm{~nm}$ (Fig. 1). It turns out that these transitions vary only within the limits $620.7 \pm 4.4,425.6 \pm 2.2$, and $315 \pm 1.5 \mathrm{~nm}$ in ten differing solvents and polymers (Table).

When the sol-gel glass is prepared at very strong acidic conditions, or impregnated by a strong acid, only the yellow $\mathrm{H}(\mathrm{MG})^{2+}$ is perceived. This has an absorption maximum [2] at 420-450 nm emitting arround $570 \mathrm{~nm}$.

A striking effect of ammonia on $\mathrm{MG}^{+}$ is also presented in Fig. 1 where a glass prepared with molar ratios of TMOS/ $\mathrm{H}_{2} \mathrm{O} /$ methacrylic acid of $1: 16: 10^{-3}$ and containing $7.4 \times 10^{-6} \mathrm{M}$ of the $\mathrm{MG}^{+}$oxalate, subsequently immersed in $0.5 \mathrm{M}$ aq. $\mathrm{NH}_{3}(\mathrm{pH}$ 11.5), decreases its absorption in the red to about a third, while the non-eluted $\mathrm{MG}^{+}$in the glass increases dramatically its quantum efficiency of $670 \mathrm{~nm}$ fluorescence from 0.003 to 0.2 .

The explanation of this unexpected behavior may be that the $\mathrm{NH}_{3}$ in solution reacts with the loosely bound $\mathrm{MG}^{+}$dis-

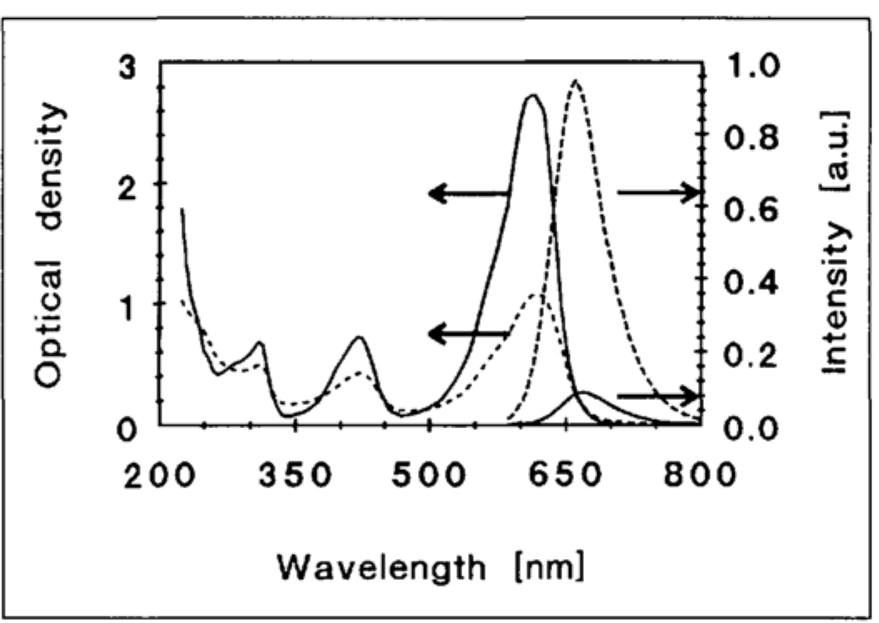

Fig. 1. Absorption and luminiscence spectra of $\mathrm{MG}^{+}$ in sol-gel bulk before (full lines) and after (dashed lines) immersion in $0.5 \mathrm{M} \mathrm{aq}$. ammonia for $24 \mathrm{~h}$. The glass was prepared from molar ratios $(\mathrm{MeO})_{4} \mathrm{Si}: 16 \quad \mathrm{H}_{2} \mathrm{O}$ : 0.001 methacrylic acid, and originally containing $7.4 \mu \mathrm{m}$ $\mathrm{MG}^{+}$oxalate. Both optical intensity and luminiscence intensity are plotted vertically in arbitrary units.

Table. Absorption Peaks [nm] of Malachite Green Oxalate in Various Media

\begin{tabular}{llll} 
Media & $\mathrm{S}_{1}$ & $\mathrm{~S}_{2}$ & $\mathrm{~S}_{3}$ \\
\hline Sol-gel bulk & 615 & 423 & 313 \\
Tetra(methoxy)silane & 619 & 422 & 313 \\
$\mathrm{H}_{2} \mathrm{O}$ & 615 & 422 & 314 \\
$\mathrm{MeOH}$ & 617 & 424 & 314 \\
$\mathrm{EtOH}$ & 619 & 425 & 314 \\
$\mathrm{PrOH}$ & 620 & 425 & - \\
$\mathrm{CHCl}_{3}$ & 621 & 425 & 315 \\
Poly(methyl methacrylate) & 625 & 425 & 316 \\
Glycerol & 627 & 429 & 317 \\
Polyvinyl alcohol & 629 & 432 & 316
\end{tabular}


solved within the cavities (perhaps also forming $\mathrm{HO}(\mathrm{MG})$ to some extent). The remaining $\mathrm{MG}^{+}$molecules become chemically bound to the silicate groups forming complexes of the type $\mathrm{R}_{3} \mathrm{C}^{+} \mathrm{OSi}(\mathrm{O} \ldots)_{3}{ }^{-}$.

When the sol-gel glass is impregnated at sufficiently low $\mathrm{pH}$, only the yellow $\mathrm{H}(\mathrm{MG})^{2+}$ is perceived, having a band close to $430 \mathrm{~nm}$ (an extreme case being $450 \mathrm{~nm}$, emitting around $570 \mathrm{~nm}$ ). Out of $29 \mathrm{differ}$ ing experimental conditions of MG-doped gel glasses, five [2] samples derived from very dilute $\mathrm{HCl}$ or $\mathrm{H}_{3} \mathrm{PO}_{4}$ (as hydrolysis and oligomerization catalyst) showed an atypical absorption band between 584 and $547 \mathrm{~nm}$, they had been dried at $55^{\circ}$ between 11 and $21 \mathrm{~d}$. The lowest wavelength $(547 \mathrm{~nm})$ corresponding to raspberry color ( $580 \mathrm{~nm}$ corresponds to blue-violet) was observed in a sample, originally containing $0.008 \mathrm{M} \mathrm{H}_{3} \mathrm{O}^{+} \mathrm{Cl}^{-}$and $3 \mathrm{M}(\mathrm{MeO})_{4} \mathrm{Si}$ in $\mathrm{H}_{2} \mathrm{O}$ (with no $\mathrm{MeOH}$ ) which had then been heated $2 \mathrm{~d}$ to $100^{\circ}$ after drying for 21 $\mathrm{d}$ at $55^{\circ}$. The absorption spectrum cannot be a superposition of bands of yellow $\mathrm{H}(\mathrm{MG})^{2+}$ and green $\mathrm{MG}^{+}$. If a novel photodecomposition process is excluded, such samples are likely to be ambiguous intermediate cases between direct coordination $\mathrm{O}_{3} \mathrm{SiO}(\mathrm{MG})$ and a quite long distance between the closest group and the central C-atom of $\mathrm{MG}^{+}$.

Fig. 2 presents three typical absorption spectra of Malachite Green in sol-gel glass- es prepared under different experimental conditions. Curve 1 is a spectrum of a standard $\mathrm{MG}^{+}$, curve 2 is the spectrum of a purple glass which was prepared with diluted $\mathrm{H}_{3} \mathrm{PO}_{4}$ as a catalyst, curve 3 has an absorption maximum at $450 \mathrm{~nm}$, is the absorption spectrum of a glass prepared under strongly acid conditions with $0.1 \mathrm{~m}$ $\mathrm{H}_{2} \mathrm{SO}_{4}$ in the starting solution, it is due to $\mathrm{H}(\mathrm{MG})^{2+}$. As stated above, the detailed preparation has been described [2] as well as generalities about such glasses [3].

Brønsted acidity involving a base $\mathrm{B}$ (with whatever charge), and its protonated form $\mathrm{BH}$ (with one charge more) has been studied in the case of Oxazine 170 [18][19]; and the highly luminescent 2,2 '-bipyridyl3,3'-diol [20] undergoing internal $\mathrm{H}$-bonding and tautomeric proton mobility in various nonviscous solvents, in polymethylmethacrylate and sol-gel glasses [3].

Another way to explain the above behavior may also involve Lewis acidity [21] where a definite (possibly proton-free) Lewis acid forms a strong adduct with a base (with a reactive pair of electrons in the Lewis paradigm [24]). Contrary to the proton affinity of a base, which can be described accordingly to Bronsted by one $\mathrm{p} K$ value in a given solvent (which can be protonated) the affinity between a Lewis acid and a given base, can not generally be described by the sum of the logarithms of an acid and a base strength. A striking case

Fig. 2. Absorption spectra of three typical sol-gel glasses. 1: Like $\mathrm{MG}^{+}$made from $1(\mathrm{MeO})_{4} \mathrm{Si}: 16 \mathrm{H}_{2} \mathrm{O}$ : 0.001 methacrylic acid and dried $10 \mathrm{~d}$ at $55^{\circ} ; 2$ : (purple species) made from 1 (MeO) ${ }_{4} \mathrm{Si}: \quad 8 \quad \mathrm{H}_{2} \mathrm{O}: \quad 11$ MeOH: $0.002 \mathrm{H}_{3} \mathrm{PO}_{4}$, dried $10 \mathrm{~d}$ at $25^{\circ}$ and then $11 \mathrm{~d}$ at $55^{\circ}$ (maximum: $552 \mathrm{~nm}[2]$ ) 3: (like $\mathrm{H}(\mathrm{MG})^{2+}$ ) made from I (MeO) ${ }_{4} \mathrm{Si}$ : $16 \mathrm{H}_{2} \mathrm{O}$ : $0.34 \mathrm{H}_{3} \mathrm{PO}_{4}$, dried $4 \mathrm{~d}$ at $55^{\circ}$. is $\mathrm{B}(\mathrm{OH})_{3}$, showing strong affinity to some bases, allowing the coordination number $\mathrm{N}$ of boron to increase from 3 to 4 . $\mathrm{InH}_{2} \mathrm{O}$ $\mathrm{B}(\mathrm{OH})_{4}{ }^{-}$is formed [25] with an effective $\mathrm{pK}=9$ of $\mathrm{H}_{2} \mathrm{O}+\mathrm{B}(\mathrm{OH})_{3}$, and at higher borate concentrations, also $\mathrm{B}_{3} \mathrm{O}_{3}(\mathrm{OH})_{4}{ }^{-}$; and $\mathrm{B}_{3} \mathrm{O}_{3}(\mathrm{OH})_{5}{ }^{2-}$ and/or $\mathrm{B}_{4} \mathrm{O}_{4}(\mathrm{OH})_{6}{ }^{2-}$ known from crystalline borax. However, $\alpha, \beta$-diols $\mathrm{R}\left(\mathrm{CH}_{2} \mathrm{OH}\right)_{2}$ react quantitavely with $\mathrm{B}(\mathrm{OH})_{3}$ to give $\mathrm{N}=4$ bidentate $\left[\mathrm{R}\left(\mathrm{CH}_{2} \mathrm{O}\right)_{2}\right]_{2} \mathrm{~B}^{-}$with so low a proton affinity that either $\mathrm{R}\left(\mathrm{CH}_{2} \mathrm{OH}\right)_{2}$ or $\mathrm{B}(\mathrm{OH})_{3}$ can be titrated as a strong Bronsted acid in presence of a large excess of the other reactant.

The coordination to boron has been shown in fluorescein (here flu ${ }^{0}$ ), existing as two tautomers in different solvents) can be [26] protonated to $[\mathrm{H}(\mathrm{flu})]^{+}$at low $\mathrm{pH}$ ( $\mathrm{p} K$ is 2.2) having a quite characteristic absorption spectrum. Molten boric acid (dehydrated to $c a$. $\mathrm{B}_{11} \mathrm{O}_{16}(\mathrm{OH})$ ) dissolves $\mathrm{flu}^{0}$, as a similar species, showing a highly unusual luminescence. At liquid air temperature, the first triplet state emits in the orange with a long lifetime. Warming up to room temperature, this emission is replaced by a greenish blue band, still with the observed lifetime of several (up to 20) $s$, at the same energy as the exceedingly rapid $\left(10^{-8} \mathrm{~s}\right)$ emission. The phenomenon is called 'delayed fluorescence', the triplet state being (very slowly) thermally excited to the first excited singlet of flu ${ }^{0}$ bound to boric acid glass. In other situations, including sol-gel glass hosts [3][27] flu ${ }^{0}$ loses two protons (one derived from a carboxylic substituent) with $\mathrm{p} K=4.4$ and 6.7 in aqueous solution [26] providing broad-band green emission (between the first excited singlet and the ground state) with quantum yield above 0.9 .

It was noted above that the purple species of MG in glass (Fig. 2) may have direct, but perhaps highly asymmetric, $\mathrm{CO}-\mathrm{Si}$ contacts. It was shown by Cigén [28] that ortho $\left.\mathrm{CH}_{3} \mathrm{OC}_{6} \mathrm{H}_{4} \mathrm{C}_{6} \mathrm{C}_{6} \mathrm{H}_{4} \mathrm{NMe}_{2}\right]_{2}{ }^{+}$ reacts with borate (diols, and polyols, e.g. mannitol) with high affinity. However, this borate adduct [28] does not connect $\mathrm{BO}-\mathrm{C}^{*}$ to the central $\mathrm{C}^{*}$-atom, but to the $\mathrm{MeO}$ group, forming a six-membered ring $\mathrm{OBOC}_{3}$. It is, of course, possible to imagine the carbinol adding $N=3$ boron. Bengtsson [10] discusses equilibria and kinetics of yellow [Gelb] $\mathrm{G}$, considered by us as (HR)CR ${ }_{2}^{2+}$, blue B $\left[\mathrm{CR}_{3}{ }^{+}\right]$, colorless $\mathrm{C}$ $\left[\mathrm{HOCR}_{3}\right]$, and the two protonated $\mathrm{S}^{\prime}$ [probably $\mathrm{H}_{2} \mathrm{OCR}_{3}{ }^{+}$] and $\mathrm{S}^{\prime \prime}$ [conceivably $\mathrm{H}_{2} \mathrm{OC}(\mathrm{RH}) \mathrm{R}_{2}^{2+}$, if not a tautomer], although his scheme on p. 1138 ascribes one more positive charge to all five species. On the other hand, Cigén gives on p.1906 of our last reference [7] the same charges as we assume. Among the corollaries are that the individual concentrations $[B] /[G]$ have the 


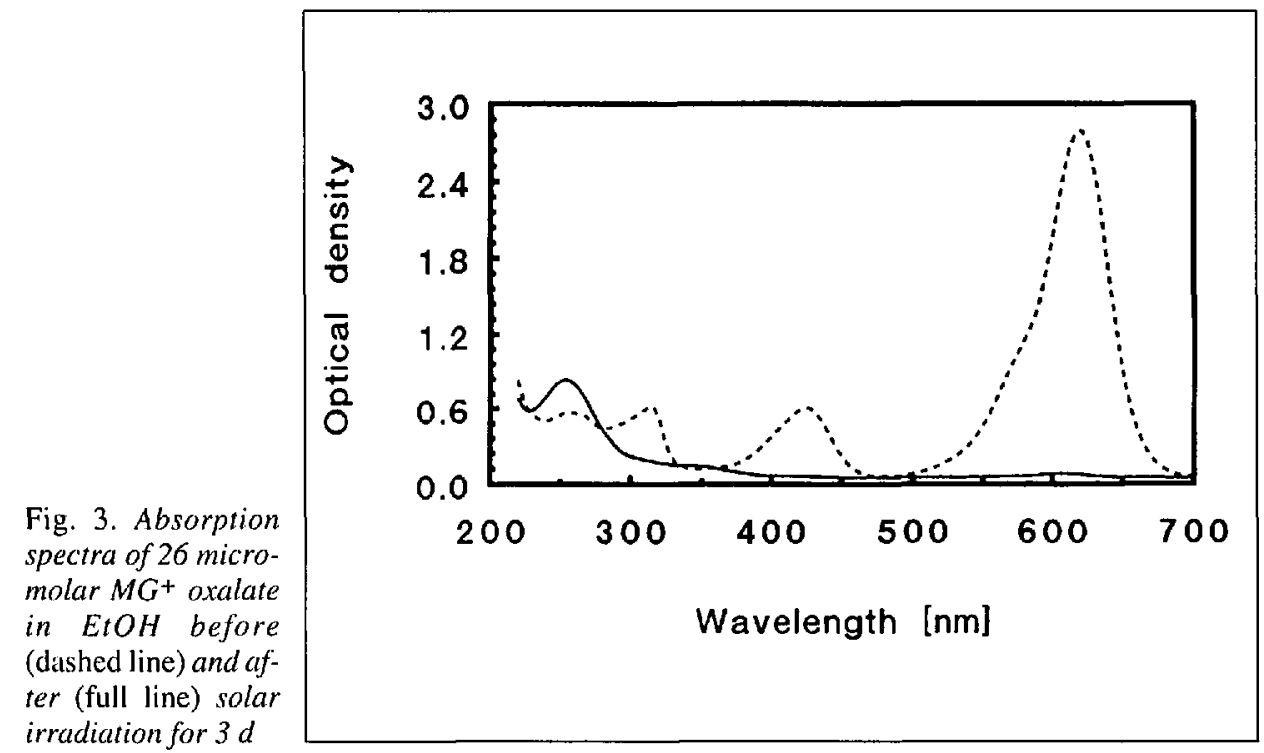

ratio 0.6 at $\mathrm{pH}=1,60$ at $\mathrm{pH}=3$, and 600000 at $\mathrm{pH}=7$, indicating $\mathrm{p} K=1.2$ of the protonated $\mathrm{G}$. The ratio $[\mathrm{B}] /\left[\mathrm{S}^{\prime}\right]$ called $[10]$ $K_{6}=9$ shows that at any $\mathrm{pH}$, a tenth of [B] $+\left[S^{\prime}\right]$ occurs at the hydrated cation of carbinol. The ratio $[\mathrm{B}] /[\mathrm{C}]$ can be evaluated [10] from $\mathrm{K}_{6} /\left(\mathrm{K}_{4}\left[\mathrm{H}^{+}\right]\right)$to be 0.0015 at $\mathrm{pH}=3,15$ at $\mathrm{pH}=7$, and 1500 at $\mathrm{pH}=9$, showing that due to equilibrium the almost colorless carbinol is predominant in alkaline solutions, all these numerical values referring to $\mathrm{HO}(\mathrm{MG})$ and $\mathrm{MG}^{+}$. The ratio $[\mathrm{B}] /\left[\mathrm{S}^{\prime \prime}\right]$ is already 80 at $\mathrm{pH}=\mathrm{l}$ and 8000 at $\mathrm{pH}=3$.

\section{Excited-State Relaxation and Photo- chemical Bleaching}

That aq. green $\mathrm{MG}^{+}$solutions slowly fade at $\mathrm{pH}$ above 6 (as mentioned above) may be due to the simple addition of $\mathrm{H}_{2} \mathrm{O}$ to give $\mathrm{HO}(\mathrm{MG})$. However, the polarographic results [10] leave the possibility of forming reduced semiquinone products (conceivably colored, but much less intensely than $\mathrm{CR}_{3}{ }^{+}$species). Thus, $26 \mathrm{mi}-$ cromolar $\mathrm{MG}^{+} \mathrm{HO}_{2} \mathrm{CCO}_{2}^{-}$in $\mathrm{EtOH}$ is almost colorless after 3-60 d in daylight, with a very weak band remaining at 580 nm (Fig. 3). Then, addition of $\mathrm{HNO}_{3}$ to make $\mathrm{pH}=\mathrm{I}$ recovers the spectrum of the green $\mathrm{MG}^{+}$.

The Bronsted acidity of $\mathrm{H}(\mathrm{MG})^{2+} e t c$. and the Lewis anti-bases $\mathrm{CR}_{3}{ }^{+}$reacting with terminal oxide groups of gel glasses are likely to render the chemistry of triphenylmethane (and related intense) colorants quite unexpected. In particular, the sol-gel method [2][3] is likely to permit observations on immobilized cations and molecules.

Experimental results on the excited state sol-gel glasses prepared from $(\mathrm{MeO})_{4} \mathrm{Si}$ and containing blue-green $\mathrm{MG}^{+}$ show [2] three absorption bands, typically at $605-616 \mathrm{~nm}$ due to the first excited singlet $S_{1}$, a weaker maximum at $411-421$ $\mathrm{nm}$ due to a second $\mathrm{S}_{2}$ (in aq. solutions [7][11][12] at $618 \mathrm{~nm}$ and $424 \mathrm{~nm}$ ), and a third band at $312 \mathrm{~nm}$ ascribed to $S_{3}$. Not only the $\mathrm{MG}^{+}$cation emits a broad band at $650 \mathrm{~nm}$ (representing a Stokes shift of $\mathrm{S}_{1}$ ), but light absorption in $S_{2}$ provides an additional emission band at $470 \mathrm{~nm}$, and in $\mathrm{S}_{3}$ still a third band at $360 \mathrm{~nm}$ [2]. Hence, a cascade transition allows emission of Stokes-shifted $S_{2}$ and $S_{1}$ from $S_{2}$ excitation, and from all three $S_{n}$ when illuminated at $300-320 \mathrm{~nm}$, the highest energy centered around $26315 \mathrm{~cm}^{-1}$.

\section{Conclusions}

Malachite Green exists in glasses as well as in other viscous materials as a strongly colored monocation or as a weaker colored dication with the central $\mathrm{C}$ atom having three carbon neighbors. Upon illumination or with addition of a base, the cations are changed reversibly to the almost colorless carbinol form in which the central atom acquires fourfold coordination. The dark green monocation in glasses exhibits fluorescence from $S_{3}, S_{2}$, and $S_{1}$ excited states. The quantum efficiency of the $S_{1}$ luminescence is about $20 \%$ at room temperature indicating relatively low nonradiative losses in this medium.

Under special experimental conditions, mainly using strong acids as catalysts for the formation of gel glasses, a purple form (possibly a complexed monocation) is formed which may also produce a shoulder close to $560 \mathrm{~nm}$ in the absorption spectrum of the green form (unless this is a vibronic excitation of $S 1$, or an excited singlet with a molar extinction coefficient of $e \approx 10^{4}$ situated between $\mathrm{S}_{1}$ and $\mathrm{S}_{2}$ ). In the ethanolic solution (Fig. 3) $\mathrm{MG}^{+}$may be bound to oxalate anions.
This communication is partially based on poster P-35 presented at the Ninth International Symposium on the Photochemistry and Photophysics of Coordination Compounds, held in Fribourg $(\mathrm{CH})$ July 14-18, 1991. The grant No. 20.27938.89 from the Swiss National Science Foundation made the collaboration possible between the Universities in Jerusalem and Genève. The Israeli Ministry of Science provided support for experimental work in Jerusalem.

Received: January 30, 1992

[1] M. Canva, G. LeSaux, P. Georges, A. Brun, F. Chaput, J.P. Boilot, Chem. Phys. Lett. 1991, 176, 495

[2] V. Chernyak, R. Reisfeld, Chem. Phys. Lett. 1991, /81, 39

[3] R. Reisfeld, C.K. Jørgensen, Struct. Bonding 1991, 77, 207.

[4] W.R. Orndorff, R.C. Gibbs, S.A. McNulty, C.V. Shapiro, J. Am. Chem. Soc: 1927, 49 , $1541,1545$.

[5] H.J. Dauben, L.R. Honnen, K.M. Harmon, J. Org. Chem. 1960, 25, 1442.

[6] M.P. Doyle, D.J. DeBruyn, D.J. Scholten, J. Org. Chem. 1973, 38, 625.

[7] R. Cigén, Acta Chem. Scand. 1958, 12 , 1456; ibid. 1960, 14, 973; ibid. 1961, 15, 1905.

[8] R. Cigén, C.G. Ekström, Acta Chem. Sccund. 1963, 17, 2083; ibid. 1964, I8, 157.

[9] C.G. Ekström, Acta Chem. Scand. 1965, 19, 1381; ibid. 1966, $20,444$.

[10] G. Bengtsson, Acta Chem. Scand. 1967, $21,1138,2544$.

[11] C.D. Ritchie, W.F. Sager, E.S. Lewis, $J$. Am. Chem. Soc. 1962, 84, 2349.

[12] A. Granzow, A. Wilson, F. Ramirez, J. Am. Chem. Soc. 1974, 96, 2454

[13] Th. Förster, G. Hoffmann, Z. Phys. Chem. N.F. 1971, 75, 63.

[14] M.D. Hirsh, H. Mahr, Chem. Phys. Lett. 1979, 60, 299.

[15] T. Robl, A. Seilmeier, Chem. Phys. Lett. 1988, 147, 544.

[16] M.M. Martin, E. Breheret, F. Nesa, Y.H. Meyer, Chem. Phys. 1989, 130, 279.

[17] E.P. Ippen, C.V.Shank, A. Bergman, Chem. Phys. Lett. 1976, 38, 611.

[18] R. Gvishi, R. Reisfeld, M. Eisen, Chem. Phys. Lett. 1989, 161, 455.

[19] R.Gvishi, R. Reisfeld, J.Non-Cryst. Solids 1991, $/ 28,69$.

[20] M.Eyal, R. Reisfeld, V.Chernyak, L. Kaczmarek, A. Grabowska, Chem. Phys. Lett. 1991, I76, 531 .

[21] G.N. Lewis, D. Lipkin, T.T. Magel, J. Am. Chem. Soc. 1941, 63, 3005.

[22] J. Bjerrum, Naturwissenschaften 1951, 38, 461.

[23] C.K. Jørgensen, Chimia 1974, 28, 605.

[24] C.K. Jørgensen, Topics Curr. Chem. 1984, 124, I; ibid. 1989, 150, 1.

[25] N. Ingri, G. Lagerström, M. Frydman, L.G. Sillen, Acta Chem. Scand. 1957, 11, 1034

[26] M.M. Martin, Chem. Phys. Lett. 1975, 35, 105; ibid. 1976, 43, 332.

[27] R. Reisfeld, M. Eyal, R. Gvishi, Chem. Phys. Lett. 1987, I38, 377.

[28] R. Cigén, Acta Chem. Scand. 1962, 16, 1271 . 